\title{
Melanocortin receptors mediate $\alpha$-MSH-induced stimulation of neurite outgrowth in Neuro 2A cells
}

\author{
R.A.H. Adan ${ }^{\text {a. } *}$, M. van der Kraan ${ }^{\text {a }}$, R.P. Doornbos ${ }^{\text {a }}$, P.R. Bär ${ }^{\text {b }}$, J.P.H. Burbach a \\ W.H. Gispen ${ }^{\text {a }}$ \\ ${ }^{4}$ Rudolf Magnus Institute for Neurosciences, Department of Medical Pharmacologn. Utrecht Unit ersity; P.O. Box 80040. Utrecht 3508 TA. The \\ Netherlands \\ ${ }^{h}$ Research Laboratory, Department of Neurology, Utrecht Unicersity, 3508 TA Utrecht, The Netherlands
}

Accepted 13 September 1995

\begin{abstract}
Melanocortins (MC), neuropeptides derived from pro-opiomelanocortin, have been implicated in enhancing neurite outgrowth via an as yet unknown mechanism. Recently, five $M C$ receptors have been identified, three of which, the $M C_{3}-R$, the $M C_{4}-R$ and the $M C_{5}-R$, are expressed in the nervous system. In this study, $\alpha$-MSH and the melanocortin analog [D-Phe ${ }^{7}$ ]ACTH (4-10) were able to stimulate neurite outgrowth in the neuroblastoma cell line Neuro 2A. ACTH (4-10), $\gamma_{2}-\mathrm{MSH}$ and ORG2766 were inactive. In addition, the $\mathrm{MC}_{4}-\mathrm{R}$ antagonist [D-Arg ${ }^{8}$ ]ACTH (4-10), inhibited the $\alpha$-MSH effect, indicating that the $\mathrm{MC}_{4}-\mathrm{R}$ mediated stimulation of neurite outgrowth by $\alpha$-MSH. Indeed, the presence of $\mathrm{MC}_{4}-\mathrm{R}$ mRNA in Neuro $2 \mathrm{~A}$ cells was demonstrated by a RNase protection assay. Heterologous expression of the $\mathrm{MC}_{5}-\mathrm{R}$ in Neuro $2 \mathrm{~A}$ cells lead to the recruitment of a responsiveness to $\gamma_{2}-\mathrm{MSH}$, but did not increase the effect of $\alpha$-MSH on neurite outgrowth. This finding indicated that the function of $\mathrm{MC}_{4}-\mathrm{R}$ can also be exerted by another $\mathrm{MC}$ receptor, suggesting that the coupling to $G_{s}$, which they have in common, plays an essential role in the neurite outgrowth promoting effect. This was further substantiated by the fact that forskolin treatment per se induced neurite outgrowth in a similar fashion. These data imply that the neurotrophic properties of $\alpha$-MSH are likely to result from $\mathrm{G}_{\mathrm{s}}$-coupled $\mathrm{MC}$ receptor activity in neuronal cells.
\end{abstract}

Keywords: Neuroblastoma: ACTH; Nerve regeneration; cAMP; Melanocortin; $G_{-}$-coupled receptor

\section{Introduction}

Neuropeptides have been implicated in the regulation of development, maturation and differentiation of the nervous system. Melanocortins are neuropeptides derived from pro-opiomelanocortin (POMC), which is expressed in pituitary lobes, in the arcuate nucleus of the hypothalamus and in the nucleus tractus solitarius of the brainstem. The presence of POMC mRNA has been demonstrated in other tissues in the rat, amongst which are the spinal cord, the dorsal root ganglion (DRG) and the sciatic nerve $[5,20,29]$. The function of melanocortins in these tissues is still unknown.

$\alpha$-Melanocyte-stimulating hormone ( $\alpha$-MSH) enhances the recovery of sensorimotor function of the hind leg after a sciatic nerve crush in rats $[4,37,38]$. Treatment of these

' Corresponding author. Fax: (31) (30) 2539032 rats with daily injections of $\alpha$-MSH increased the number of neurofilament positive fibres in the regenerating stump of the crushed nerves [39], indicating that the enhancement of recovery of sensorimotor function by $\alpha$-MSH was due to a stimulation of the number of sprouts formed in the damaged nerve. Treatment of primary cultures of avian embryonic as well as rat embryonic DRG cells and rat embryonic spinal cord cells with $\alpha$-MSH increased the number and length of the neurites formed $[16,19,35,36]$. These data demonstrated that there may be a direct effect of $\alpha$-MSH on the neurons of the DRG and spinal cord. implicating a role for melanocortin receptors.

To date, five melanocortin receptor (MC-R) subtypes have been identified $[3,7-9,12-15,24-26,30]$. Three of these, $M C_{3}-R, M C_{4}-R$ and $M C_{5}-R$ are expressed in the nervous system. The $M_{1}-R$ (the MSH receptor) is expressed in melanocytes, whereas the $\mathrm{MC}_{2}-\mathrm{R}$ is the ACTH receptor expressed in the adrenal gland. Although the expression of the $M C_{3}-R$ is restricted mainly to the hypo- 
thalamus, $\mathrm{MC}_{4}-\mathrm{R}$ and $\mathrm{MC}_{5}-\mathrm{R}$ have a more widespread expression in brain $[14,15,24,26,30]$. Although all $M C$ receptors, except $\mathrm{MC}_{2}-\mathrm{R}$, are activated by low doses of $\alpha$-MSH, the activation of different MC receptors can be studied by the use of more selective MC ligands such as $\gamma_{2}$-MSH which does not activate the $\mathrm{MC}_{4}-\mathrm{R}$, but is a potent activator of the $\mathrm{MC}_{3}-\mathrm{R}[1,30]$.

MC receptors all couple to the cAMP signal transduction pathway. Indeed, cAMP has been shown to stimulate neurite elongation both in vitro as well as in vivo. Daily injections with dibutyryl cAMP (dbcAMP) enhanced the recovery of sensorimotor function in rats after a sciatic nerve crush [28]. cAMP analogs promote neurite outgrowth in cultures of rat sympathetic and sensory neurons [31]. The stimulation of neurite outgrowth by forskolin and/or dbcAMP has been reported for several neuroblastoma cell lines $[22,23,27]$. These data suggest that modulation of the cAMP signal transduction pathway influences neurite outgrowth. This implicates $\mathrm{G}_{\mathrm{s}}$-coupled receptors in the regulation of neurite outgrowth.

Here we aimed at determining whether MC receptor activation modulates neurite outgrowth. Therefore, we investigated the effect of $\alpha$-MSH on neurite outgrowth in Neuro $2 \mathrm{~A}$ cells and the involvement of $\mathrm{MC}$ receptors in this process.

\section{Materials and methods}

\subsection{Peptides and drugs}

ORG2766, ACTH (4-10) and [D-Phe ${ }^{7}$ ACTH (4-10) were provided by Organon International (Oss, The Netherlands). ACTH (4-10) and [D-Phe ]ACTH (4-10) have a free $\mathrm{N}^{\alpha}$-amino group and carboxyl terminus. ORG2766 is $\operatorname{Met}\left(\mathrm{O}_{2}\right)$-Glu-His-Phe-D-Lys-Phe. Peptides were dissolved and diluted in Hanks' balanced salt solution (HBBS). Forskolin, geniticin (G418), nerve growth factor ( $\beta$-NGF), $\alpha$-MSH and isobutylmethoxyxanthine (IBMX) were from Sigma (Bornum, Belgium). $\gamma_{2}-\mathrm{MSH}$ was from Bachem (Feinchemikalien, Bubendorf, Switzerland).

\subsection{Cells and stable transfection}

Mouse neuroblastoma Neuro 2A cells were grown in Dulbecco's modified Eagle's medium (DMEM) supplemented with $10 \%$ fetal calf serum. Neuro $2 \mathrm{~A}$ cells stably expressing the mouse $\mathrm{MC}_{5}-\mathrm{R}$ were generated by transfection of Neuro $2 \mathrm{~A}$ cells with $10 \mu \mathrm{g}$ of pCMVneo/ $/ \mathrm{MC}_{5}-\mathrm{R}$ (encoding the mouse $M_{5}-\mathrm{R}$ [14]), using the calciumphosphate precipitation method as described previously [34]. Stably expressing clones of cells were selected in G418 supplemented medium for 4 weeks. The expression of $\mathrm{MC}_{5}-\mathrm{R}$ was confirmed by measurement of the cAMP content of cells treated for $30 \mathrm{~min}$ with $1 \mu \mathrm{M} \alpha$-MSH as compared to non-transfected cells.

\section{3. cAMP assay}

Neuro $2 \mathrm{~A}$ cells (wild-type or expressing the $\mathrm{MC}_{5}-\mathrm{R}$ ) were washed once with HBSS (supplemented with $2 \mathrm{mM}$ calcium-chloride and $0.1 \mathrm{mM}$ IBMX), and treated for 30 min with ACTH peptides or forskolin in HBSS. Cells were harvested in $0.5 \mathrm{ml}$ of HBSS supplemented with $0.02 \%$ Triton X-100 and centrifuged for $15 \mathrm{~min}$ at $12000 \times \mathrm{g}$. 50 $\mu l$ of the supernatant was succinylated, and the cAMP content was determined using the cAMP-RIA-kit from Sigma [11].

\subsection{Quantification of neurite length}

Neuro $2 \mathrm{~A}$ cells were harvested and plated onto poly(Llysine)-coated 12-wells cluster plates (Costar, Cambridge, MA) at a $2 \%$ confluency. Cells were incubated with different doses of $\alpha$-MSH, ACTH analogs, $\beta$-NGF or forskolin in chemically defined medium (DMEM supplemented with $20 \mu \mathrm{g}$ transferrin, $20 \mathrm{nM}$ progesterone, 100 $\mu \mathrm{M}$ putrescine, $30 \mathrm{nM}$ sodiumselinate and $5 \mu \mathrm{g} / \mathrm{ml}$ insulin) for $24 \mathrm{~h}$. Cells were washed once with phosphatebuffered saline (PBS), fixed in $2 \%$ formaldehyde in water for 20 min and stained with either Coomassie brilliant blue in PBS for $3 \mathrm{~min}$ to intensify contours of neurites or immunostained with a neurofilament monoclonal antibody RT97 (Boehringer, Mannheim, Germany) as described previously [36]. Neurite length of Coomassie brilliant blue stained cells was measured by an automated system (TIM) which measures the amount of pixels in the surface area of neurites [21]. The average and standard error of the mean were determined in 5 separate wells incubated with the same concentration of drug.

\subsection{Galactosidase assay}

Neuro $2 \mathrm{~A}$ cells (wild-type or expressing the $\mathrm{MC}_{5}-\mathrm{R}$ ) were transfected with PCREGAL [6] as described above. $20 \mathrm{~h}$ after transfection, cells were plated onto 96-wells plates (Costar, Cambridge, MA). The next day, cells were treated for 6 hours with $\alpha$-MSH, $\gamma_{2}-\mathrm{MSH}$ or forskolin in DMEM supplemented with $0.5 \%$ bovine serum albumin and $0.1 \mathrm{mM}$ IBMX. Subsequently, galactosidase activity was determined as described previously [6] and the absorbance was measured at $405 \mathrm{~nm}$ in a microplate reader (Bio-Rad Laboratories, Richmond, CA).

\subsection{RNase protection assay}

RNase protection assays were performed as described previously [32]. Briefly, a $312 \mathrm{bp}$ fragment of the rat $\mathrm{MC}_{3}-\mathrm{R}(+592$ to +904 relative to the translation initiation codon), a $155 \mathrm{bp}$ fragment of the rat $\mathrm{MC}_{4}-\mathrm{R}$ (derived from the $3^{\prime}$ end of the $600 \mathrm{bp}$ rat $\mathrm{MC}_{4}-\mathrm{R}$ fragment isolated by Mountjoy et al. [26]), a $198 \mathrm{bp}$ fragment of the rat $\mathrm{MC}_{5}-\mathrm{R}(+402$ to +600 relative to the translation initia- 
A

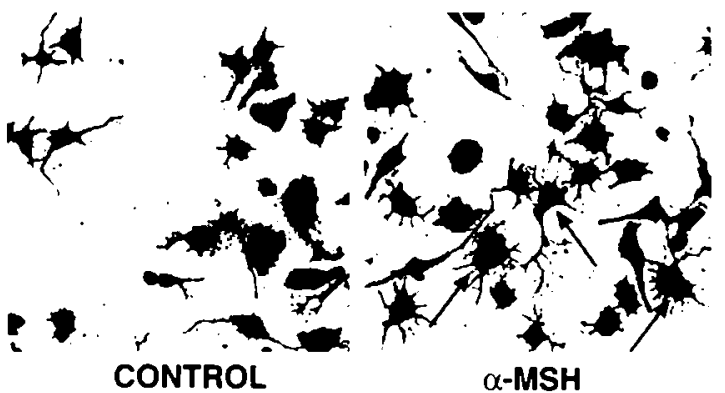

CONTROL

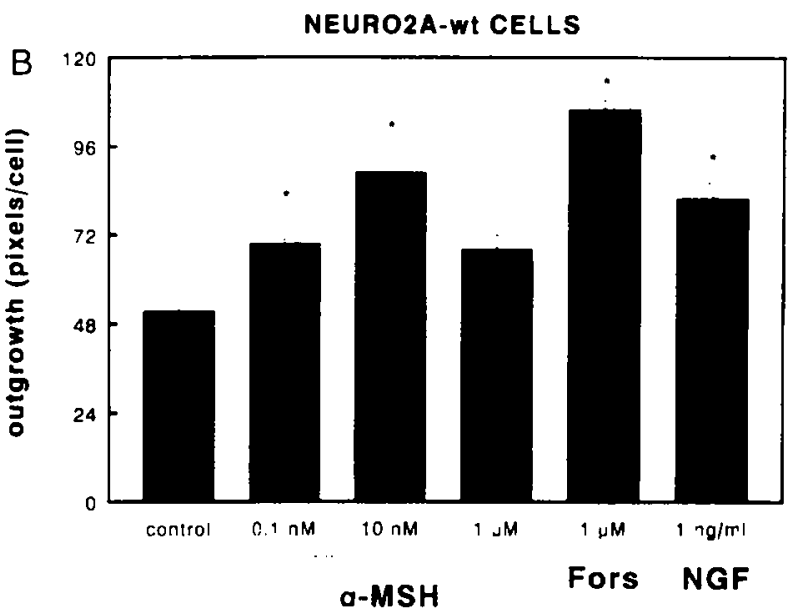

Fig. 1. Stimulation of neurite outgrowth in Neuro $2 \mathrm{~A}$ cells. A: Neuro 2a cells treated for $24 \mathrm{~h}$ with $10 \mathrm{nM} \alpha$-MSH (right), as compared to control cells (left). The cells were stained with Coomassie brilliant blue to increase the contrast in neurites. Note that upon $\alpha$-MSH treatment part of the cells acquire a different phenotype. Arrows point to the typical appearance of three of these cells. B: Neuro $2 A$ cells were incubated with $\alpha$-MSH, $1 \mu \mathrm{M}$ forskolin (Fors) or $1 \mathrm{ng} / \mathrm{ml} \beta$-NGF (NGF). After $24 \mathrm{~h}$, mean neurite length was measured. Data are expressed as average with standard error of the mean. An asterisk (*) indicates a statistically significant $(P<0.05)$ difference as compared to the control treatment (incubation medium only) as determined by an ANOVA followed by a Bonferroni $t$-test.

tion site) and a 55 bp fragment of rat GAPDH ( +178 to +233 relative to the translation initiation site) were used for the synthesis of antisense ${ }^{32} \mathrm{P}$-labelled RNA probes ([ $\left.\alpha-{ }^{32} \mathrm{P}\right] \mathrm{CTP}, 800 \mathrm{Ci} / \mathrm{mmol}$, Amersham). Antisense labelled GAPDH probe was used as internal standard to

Table 1

Neuro 2a cells (wild type) were treated with different doses $\left(10^{-10}, 10^{-8}\right.$ or $10^{-6} \mathrm{M}$ ) of $\alpha$-or $\gamma_{2}$-MSH and ACTH analogs

\begin{tabular}{lc}
\hline Peptide & Neurite outgrowth \\
\hline$\alpha$-MSH & $10^{-10} \mathrm{M}$ \\
$\gamma_{2}$-MSH & - \\
ACTH $(4-10)$ & - \\
[D-Phe']ACTH $(4-10)$ & $10^{-\gamma} \mathrm{M}$ \\
ORG2766 & - \\
\hline
\end{tabular}

The lowest dose that stimulated neurite outgrowth statistically significantly (as determined by an ANOVA followed by a Bonferroni $t$-test $(P<0.05))$ was determined and is indicated in the table. A minus $(-)$ indicates that no statistically significant stimulation of outgrowth was observed. control for experimental variability. Total RNA was isolated from the cell lines as described previously by Wilkinson [40]. RNA samples $(25 \mu \mathrm{g})$ were overnight incubated
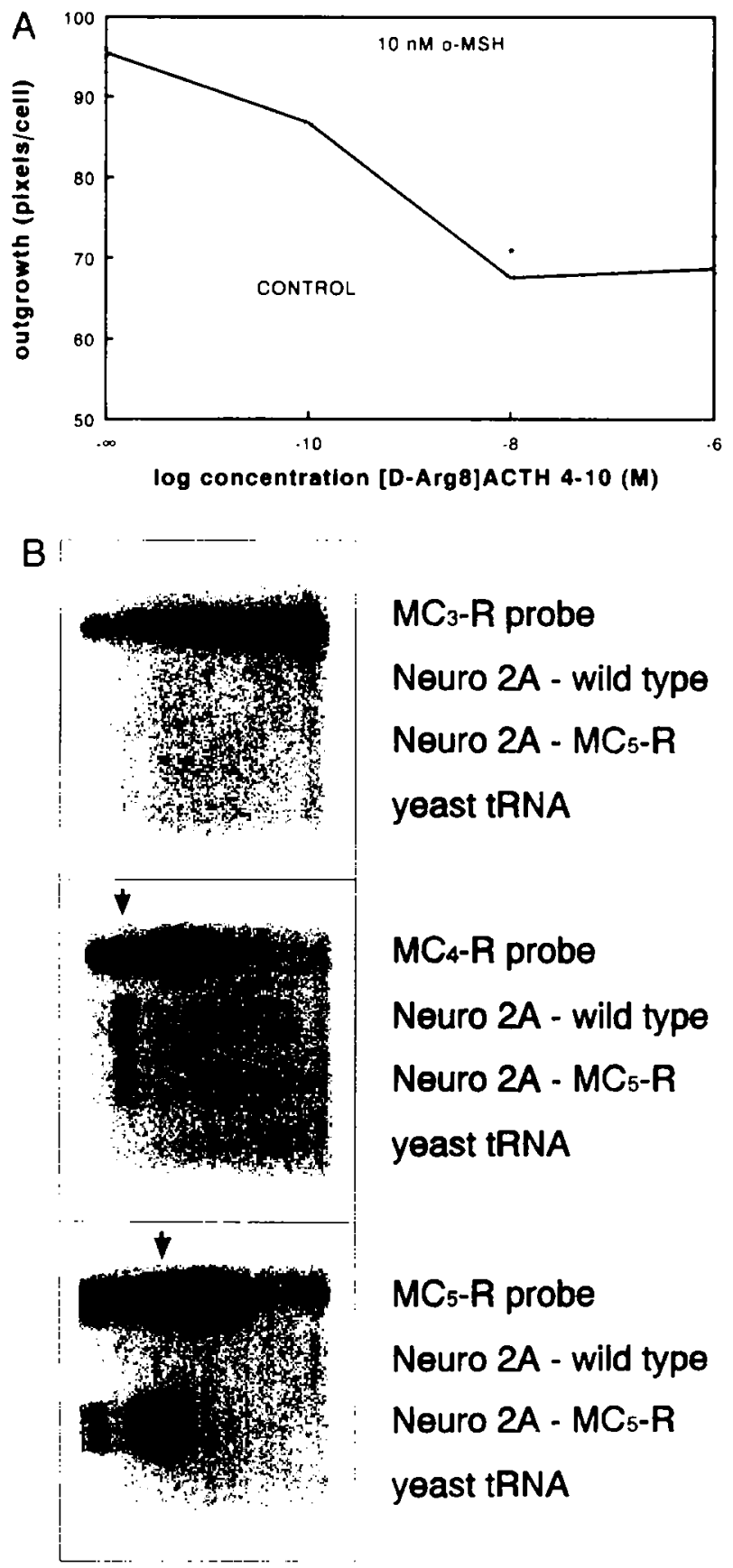

$\mathrm{MC}_{3}-\mathrm{R}$ probe

Neuro 2A - wild type

Neuro 2A - MC5-R

yeast tRNA

MC4-R probe

Neuro 2A - wild type

Neuro 2A - MC5 $-\mathrm{R}$

yeast tRNA

\section{MC5-R probe}

Neuro 2A - wild type

Neuro 2A - MC5-R

yeast tRNA

Fig. 2. A: Neuro $2 \mathrm{~A}$ cells were incubated with $10 \mathrm{nM}$ of $\alpha$-MSH in the presence of increasing doses of [D-Arg ${ }^{\mathrm{K}}$ ]ACTH (4-10). After $24 \mathrm{~h}$, neurite length was measured. Data are expressed as average with standard error of the mean. An asterisk $(*)$ indicates a statistically significant $(P<0.05)$ difference as compared to the control treatment $(10 \mathrm{nM}$ $\alpha$-MSH) as determined by an ANOVA followed by a Bonferroni $t$-test. Dotted lines indicate the neurite formation after treatment with $10 \mathrm{nM}$ $\alpha$-MSH (upper line) or control (lower line) for $24 \mathrm{~h}$. B: RNase protection assay on $25 \mu \mathrm{g}$ total RNA prepared from wild-type Neuro $2 \mathrm{~A}$ cells or Neuro $2 A$ cells expressing $M C_{5}-R s$, using $M C_{3}-R, M C_{4}-R$ and $M C_{5}-R$ probes. Probe lanes show the undigested probe. Arrows indicate protected fragments. 
at $50^{\circ} \mathrm{C}$ with $5000 \mathrm{cpm}$ of labelled antisense $\mathrm{MC}$ receptor probe and $50000 \mathrm{cpm}$ of labelled antisense GAPDH probe. After digestion with RNase A $(4 \mu \mathrm{g} / \mathrm{ml})$ and $T_{1}(0.2$ $\mu \mathrm{g} / \mathrm{ml}$ ), samples were analyzed by electrophoresis on a denaturing $6 \%$ polyacrylamide gel and autoradiographed. These low RNase concentrations were used to prevent cleavage of occasional nucleotide mismatches between the rat probes and the highly homologous mouse target RNAs. In these conditions, no crosshybridisation could be detected between the $M_{3}-R, M C_{4}-R$ and $M C_{5}-R$. The protected mouse target $\mathrm{RNAs}$ had the expected length as could be judged from positive control RNA samples and molecular weight markers run in parallel.

\section{Results}

\subsection{Stimulation of neurite outgrowth}

In order to investigate the mechanism via which $\alpha$-MSH stimulates neurite outgrowth and functional recovery after nerve damage, we investigated whether $\alpha$-MSH was able to stimulate neurite outgrowth in neuroblastoma cell lines. In the neuroblastoma cell line Neuro 2A, $\alpha$-MSH stimulated neurite outgrowth $70 \%$ above the spontaneous outgrowth that occurs after removal of fetal calf serum from the incubation medium. $\alpha$-MSH clearly stimulated the number of neurofilament positive sprouts (Fig. 1A). Fig. $1 \mathrm{~B}$ shows the effect of $\alpha$-MSH on the mean length of neurites of the Neuro $2 \mathrm{~A}$ cell line as compared to treatment with $1 \mathrm{ng} / \mathrm{ml} \beta$-NGF (nerve growth factor) and 1 $\mu \mathrm{M}$ forskolin. In these cells, $\alpha$-MSH and $\beta$-NGF had a similar effect. Higher doses of $\beta$-NGF ( 3 and $10 \mathrm{ng} / \mathrm{ml}$ ) did not increase the effect of $\beta$-NGF on neurite outgrowth.

\subsection{Melanocortin receptor involvement in neurite out- growth}

To investigate which melanocortin receptor subtype mediated this effect of $\alpha$-MSH on Neuro $2 \mathrm{~A}$ cells, we compared the activity of different melanocortins (ACTH (4-10), [D-Phe ${ }^{7}$ ACTH (4-10), $\gamma_{2}$-MSH, ORG2766 and

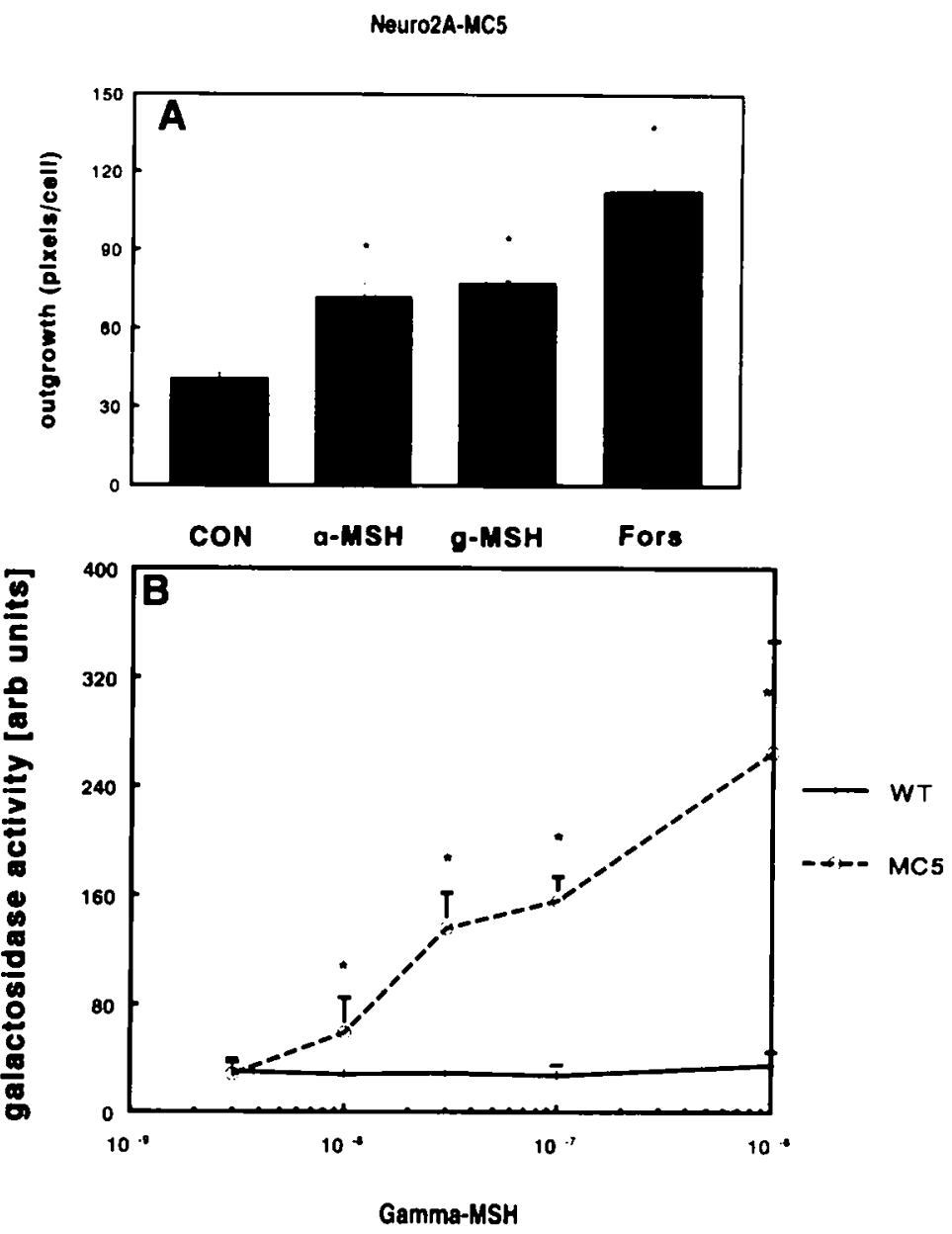

Fig. 3. A: Neuro 2A cclls, stably expressing $\mathrm{MC}_{5}-\mathrm{R}$, werc treated with $10 \mathrm{nM} \alpha-\mathrm{MSH}, 10 \mathrm{nM} \gamma_{2}-\mathrm{MSH}(\gamma$-MSH) or $1 \mu \mathrm{M}$ forskolin (Fors). After 24 h neurite outgrowth was measured. An asterisk $(*)$ indicates a statistically significant $(P<0.05)$ difference as compared to the control $(C O N)$ treatment as determined by an ANOVA followed by a Bonferroni $t$-test. B: Wild-type Neuro $2 \mathrm{~A}$ cells (WT) and Neuro $2 \mathrm{~A}$ cells stably expressing $\mathrm{MC} \mathrm{C}_{5} \cdot \mathrm{Rs}_{5}(\mathrm{MC} 5)$ were transfected with the PCREGAL plasmid to measure activation of the cAMP signal transduction pathway by $\gamma_{2}$-MSH $(\gamma-$ MSH $)$. An asterisk $(*)$ indicates a statistically significant $(P<0.05)$ difference as compared to the control treatment as determined by an ANOVA followed by a Bonferroni $t$-test. 
$\alpha-\mathrm{MSH}$ ) in this assay (Table 1). This set of melanocortins enabled us to discriminate between the activation of different $\mathrm{MC}$ receptor subtypes. The structure activity relation-
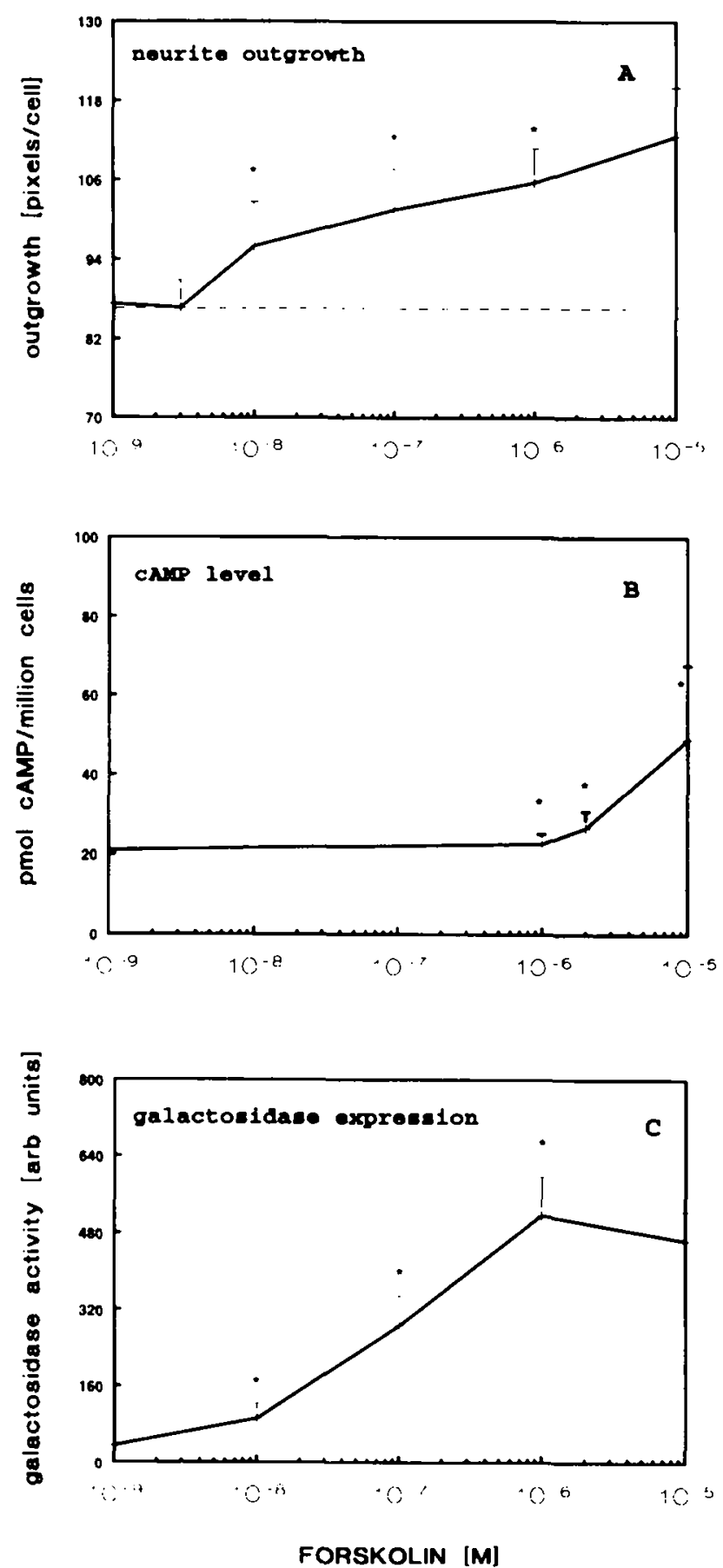

Fig. 4. A: Neuro 2A cells were incubated with forskolin. Neurite length was measured as described in the materials and methods section. Data are expressed as average with standard error of the mean. B: Neuro $2 \mathrm{~A}$ cells were treated with forskolin and whole cell extracts were prepared to measure the CAMP content. C: Neuro 2A cells were transfected with the PCREGAL plasmid to measure activation of the cAMP signal transduction pathway by forskolin. An asterisk (*) indicates a statistically significant $(P<0.05)$ difference as compared to the control treatment (incubation medium (only) as determined by an ANOVA followed by a Bonferroni $t$-test. ship (SAR) of melanocortins able to stimulate neurite outgrowth in Neuro 2A cells fitted best with the SAR of the $\mathrm{MC}_{4}-\mathrm{R}$ [1]: $\alpha$-MSH $\left(10^{-10} \mathrm{M}\right)$ and [D-Phe ${ }^{7}$ ACTH (4-10) $\left(10^{-8} \mathrm{M}\right)$ stimulated neurite outgrowth, whereas the $\mathrm{EC}_{50}$ values for these ligands on stimulating cAMP levels in $293 \mathrm{HEK}$ cells were $10^{-8}$ and $10^{7} \mathrm{M}$, respectively. Furthermore, ACTH (4-10), $\gamma_{2}-\mathrm{MSH}$ and ORG2766 were inactive on neurite outgrowth. These compounds were inactive (ORG2766) or only poorly activated the $\mathrm{MC}_{4}-\mathrm{R}[1,33]$. In order to further investigate the involvement of the $\mathrm{MC}_{4}-\mathrm{R}$, we incubated Neuro $2 \mathrm{~A}$ cells with $10 \mathrm{nM} \alpha-\mathrm{MSH}$ in the presence of increasing doses of the $\mathrm{MC}_{4}-\mathrm{R}$ antagonist [D-Arg ${ }^{8}$ ]-ACTH (4-10) [2]. Fig. 2A shows that this antagonist inhibited the effect of $\alpha-\mathrm{MSH}$ dose dependently. A RNase protection assay demonstrated that wild-type Neuro $2 \mathrm{~A}$ cells express the $\mathrm{MC}_{4}-\mathrm{R}$ at low levels (Fig. 2B). Although $25 \mu \mathrm{g}$ of total RNA was used in the RNase protection assay, we had to expose films for 2 weeks with intensifying screens to visualize this signal.

We further tested the hypothesis that MC receptors mediated MSH-induced neurite outgrowth in Neuro $2 \mathrm{~A}$ cells, by stably expressing another $\mathrm{MC}$ receptor subtype (the mouse $\mathrm{MC}_{5}-\mathrm{R}$ ) in Neuro $2 \mathrm{~A}$ cells. This enabled us to determine: (1) whether a higher level of $\mathrm{MC}$ receptor expression would increase the effect of $\alpha$-MSH on neurite outgrowth; (2) whether a selective MC ligand, $\gamma_{2}-\mathrm{MSH}$, that does not activate the $\mathrm{MC}_{4}-\mathrm{R}$ and which was inactive to stimulate neurite outgrowth in wild-type Neuro 2A cells, would now stimulate neurite outgrowth in $\mathrm{MC}_{5}-\mathrm{R}$ transfected cells. We confirmed the expression of the $M C_{5}-R$ in these stably transfected cells by a RNase protection assay (Fig. 2B). In wild-type Neuro $2 \mathrm{~A}$ cells, we could not detect $M C_{5}-R$ expression. The amount of $M_{5}-R$ mRNA in stably transfected Neuro 2A cells was 9-fold higher as compared to the amount of $\mathrm{MC}_{4}-\mathrm{R}$ mRNA in both wildtype and stably transfected Neuro $2 \mathrm{~A}$ cells after correction for the total amount of RNA using the GAPDH signal as internal reference. However, the effect of $\alpha$-MSH on neurite outgrowth in transfected Neuro 2A cells was not higher than the effect of $\alpha$-MSH on wild-type Neuro 2A cells (Figs. 1 and $3 \mathrm{~A}$ ). But $\gamma_{2}-\mathrm{MSH}$ now stimulated neurite outgrowth in stably transfected Neuro $2 \mathrm{~A}$ cells expressing the $\mathrm{MC}_{5}-\mathrm{R}$ (Fig. 3A). This is in line with the fact that $\gamma_{2}-\mathrm{MSH}$ was able to stimulate the cAMP signal transduction pathway in Neuro $2 \mathrm{~A}$ cells expressing the $\mathrm{MC}_{5}-\mathrm{R}$ (Fig. 3B). $\gamma_{2}-\mathrm{MSH}$ did not activate the CAMP signal transduction pathway in wild-type Neuro $2 \mathrm{~A}$ cells that express $\mathrm{MC}_{4}$-Rs nor did it stimulate neurite outgrowth.

\subsection{Actication of the cAMP signal transduction pathway and neurite outgrowth}

To investigate whether direct stimulation of the cAMP pathway in wild-type Neuro $2 \mathrm{~A}$ cells was able to stimulate neurite outgrowth, these cells were treated with forskolin. 
Forskolin stimulated neurite outgrowth in Neuro 2A cells (Fig. 4A). Forskolin stimulated cAMP accumulation in Neuro 2A cells dose dependently (Fig. 4B). However, the dose necessary to increase cAMP levels $(1 \mu \mathrm{M})$ was 100 -fold higher as compared to the dose necessary to stimulate neurite outgrowth (10 nM). This discrepancy was also found for $\alpha$-MSH. $1 \mu \mathrm{M} \alpha$-MSH did not stimulate cAMP accumulation in wild-type Neuro $2 \mathrm{~A}$ cells whereas $0.1 \mathrm{nM} \alpha$-MSH already stimulated neurite outgrowth. Therefore, Neuro 2A cells were transfected with a CRELacZ plasmid and galactosidase activity was measured following treatment with forskolin. This is a more sensitive method for determining activation of the cAMP pathway [6]. Fig. 4C shows the dose response curve of forskolin on galactosidase activity in Neuro $2 \mathrm{~A}$ cells. $10 \mathrm{nM}$ forskolin, which was the lowest dose able to stimulate neurite outgrowth, was also the lowest dose to increase galactosidase activity.

\section{Discussion}

Melanocortins stimulate neurite outgrowth, as has been reported both in in vivo as well as in in vitro models $[4,16,19,35-38]$. The mechanism via which melanocortins mediate their effect on neurite outgrowth is unclear, one reason being that the expression of melanocortin receptors in putative target tissues involved in the regeneration process (amongst which are spinal cord motoneurons and sensory neurons of the dorsal root ganglion) is still unknown. In addition, we do not know what function melanocortin receptor expression has, when expressed and activated in neurons. Therefore, we studied the effect of melanocortin receptor activation in a neuronal cell line. We here demonstrate that $\alpha$-MSH stimulates neurite outgrowth in a neuroblastoma cell line, Neuro $2 \mathrm{~A}$. The stimulatory effect of $10 \mathrm{nM} \alpha$-MSH on neurite outgrowth in this cell line was of the same magnitude as that of $1 \mathrm{ng} / \mathrm{ml}$ $\beta$-NGF. In other systems, higher doses of $\beta$-NGF (up to $15 \mathrm{ng} / \mathrm{ml}$ ) were needed for a maximal response on neurite outgrowth in DRG cultures [36]. This indicates that Neuro $2 \mathrm{~A}$ cells are sensitive for $\beta$-NGF at a relatively low dose. $\gamma_{2}$-MSH, ORG2766 and ACTH (4-10) were inactive, whereas [D-Phe ${ }^{7}$ ACTH (4-10) was active in stimulating neurite outgrowth in Neuro $2 \mathrm{~A}$ cells (Table 1), suggesting the involvement of $\mathrm{MC}_{4}-\mathrm{Rs}$, since the SAR of MCs on the activity of this receptor expressed on $293 \mathrm{HEK}$ cells fits exactly [1]. This was confirmed by inhibition of $\alpha$-MSH stimulated neurite outgrowth by a $\mathrm{MC}_{4}-\mathrm{R}$ antagonist and by demonstration of endogenous $\mathrm{MC}_{4}-\mathrm{R}$ expression using a RNase protection assay (Fig. 2). ORG2766, which is an ACTH (4-9) analog with no activity on the MC receptor $[1,30]$ was not able to stimulate neurite outgrowth in Neuro 2 A cells. This underscores the selectivity of melanocortins for stimulating melanocortin receptors in neuronal cell types.
In Neuro $2 \mathrm{~A}$ cells expressing the $\mathrm{MC}_{5}-\mathrm{R}, \gamma_{2}-\mathrm{MSH}$ was able to stimulate neurite outgrowth whereas this compound was ineffective in wild-type Neuro 2A cells (Fig. 4B). This indicates that $\mathrm{MC}_{4}$-Rs can be substituted by other $\mathrm{MC}$ receptors for the mediation of $\alpha$-MSH-stimulation of neurite outgrowth. Although the transfected cells expressed high levels of $\mathrm{MC}_{5}-\mathrm{R}$ mRNA, the effect of $\alpha$-MSH on neurite outgrowth was not increased as compared to its effect on wild-type cells. Apparently, the neurite outgrowth response by melanocortin receptor activation was already maximal and could not be increased by raising the expression of melanocortin receptors. We reasoned that above a certain cAMP level, neurite outgrowth would not be increased any further. Therefore, it was investigated whether forskolin, which activates adenylate cyclase directly, was also able to stimulate neurite outgrowth in Neuro 2A cells. This was indeed the case, but the dose necessary to stimulate neurite outgrowth $(10 \mathrm{nM})$ was much lower than the dose necessary to increase cAMP levels as determined by radioimmunoassay $(1 \mu \mathrm{M})$. This is in line with the reports of $\mathrm{Hol}$ et al. $[17,18]$ who demonstrated that cAMP levels were increased in embryonic DRG cultures only by high doses of $\alpha$-MSH, whereas lower doses of $\alpha$-MSH already elicited an effect on neurite outgrowth. Thus, it may be that in the studies of $\mathrm{Hol}$ et al., the level of $\mathrm{MC}$ receptor expression was high enough to mediate effects of $\alpha$-MSH on neurite outgrowth, but not high enough to detectably increase cAMP levels at low concentrations of $\alpha$-MSH. Using the CRE-LacZ as a reporter gene, $10 \mathrm{nM}$ was the lowest dose of $\alpha$-MSH that increased galactosidase levels in wild-type Neuro $2 \mathrm{~A}$ cells statistically significant above basal levels. This indicated that although the cAMP signal transduction pathway was activated, it did not raise cAMP levels above basal in whole cell extracts of wild-type Neuro $2 \mathrm{~A}$ cells. However, using the galactosidase assay, the concentration of $\alpha$-MSH (10 $\mathrm{nM}$ ) necessary to activate $\mathrm{MC}$ receptors was closer to the concentration $(0.1 \mathrm{nM})$ necessary to increase neurite outgrowth.

There may be several reasons for the discrepancies that we observed in the dose of $\alpha$-MSH necessary to increase cAMP levels, galactosidase activity and neurite outgrowth in Neuro 2A cells: (1) local rises in cAMP levels in neurites may be relevant to the process of neurite elongation rather than the whole cell content of cAMP; these local increases in cAMP level are not detected when measuring the whole cell content of CAMP by a radioimmunoassay; (2) the dynamics of the activation of the cAMP signal transduction pathway may be important for the effect on neurite outgrowth; note that cAMP levels were measured $30 \mathrm{~min}$ after treatment of Neuro $2 \mathrm{~A}$ cells with drug, whereas galactosidase activity and neurite outgrowth were measured after 6 and $24 \mathrm{~h}$, respectively; (3) there may be a threshold level of cAMP above which neurite outgrowth is stimulated; note that overexpression of $\mathrm{MC}_{5}-\mathrm{R}$ in Neuro $2 \mathrm{~A}$ cells did not increase the effect of 
$\alpha$-MSH on neurite outgrowth (Fig. 3B). Taken together, these data suggest that there is no linear correlation between cAMP levels and neurite outgrowth. However, the presence of MC receptors is necessary for MSH to stimulate neurite outgrowth.

It has been demonstrated that local application of $\alpha$ MSH near the crush lesion site is effective in stimulating nerve regeneration [10]. Since cAMP levels were raised in cultured neurons, but not in cultured Schwann cells, upon treatment with $\alpha$-MSH [18], this effect is probably mediated via $M C$ receptors present on neurons. In analogy with what we describe here for Neuro $2 \mathrm{~A}$ cells, it may be that the regenerating neurons in the crush model that originate in the DRG, have $\mathrm{MC}$ receptors on their neurites that are stimulated by $\alpha-\mathrm{MSH}$, leading to local activation of the cAMP signal transduction pathway which in turn may stimulate neurite elongation. Future studies are directed to answer this question.

\section{Acknowledgements}

We thank Julia Oosterom for determination of cAMP levels using a radioimmunoassay, and dr. Elly $M$. Hol for her assistance in pilot studies measuring neurite outgrowth in Neuro 2A cells. We thank Dr. Ira Gantz for providing the mouse $\mathrm{MC}_{5}$ receptor expression vector.

\section{References}

[1] Adan. R.A.H., Cone, R.D.. Burbach, J.P.H. and Gispen, W.H., Differential effects of melanocortin peptides on neural melanocortin receptors, Mol. Pharmacol. 46 (1994) 1182-1190.

[2] Adan, R.A.H., Oosterom, J., Ludvigsdottir, G., Brakkee, J.H., Burbach. J.P.H. and Gispen, W.H., Identification of antagonists for MC3, MC4 and MC5 receptors, Eur. J. Pharmacol, 269 (1994) 3.31-3.37.

[3] Barrett, P., MacDonald, A., Helliwell, R., Davidson, G. and Morgan, P., Cloning and expression of a ncw member of the melanocytestimulating hormone receptor family. J. Mol. Endocrinol., 12 (1994) 2013-213.

[4] Bijlsma, W.A., Schotman, P., Jennekens, F.G.I., Gispen, W.H. and De Wied, D.. The enhanced recovery of sensorimotor fuction in rats is related to the melanotropic moiety of ACTH/MSH neuropeptides, Eur. J. Pharmacol., 92 (1983) 231-236.

[5] Carr, A. and Haynes, L.W., Transient appearance of propiomelanocortin (POMC) messenger RNA and N-terminal peptides in rat embryo spinal cord, Neurosci. Res. Commun., 3 (1988) 31-40.

[6] Chen, W.. Shields, T.S., Stork, P.J.S. and Cone, R.D., A colorimetric assay for measuring activation of $\mathrm{Gs}$ and $\mathrm{Gq}$ coupled signaling pathways. Anal. Biochem., 226 (1995) 349-354.

[7] Chhajlani. V and Wikberg, J.E.S., Molecular cloning and expression of the human melanocyte stimulating hormone receptor cDNA. FEBS Lett., 309 (1992) 417-420.

[8] Chhajlani, V.. Muceniece, R. and Wikberg, J.E.S., Molecular cloning of a novel human melanocortin receptor, Biochem. Biophys. Res. Commun., 195 (1993) 866-873.

[9] Desarnaud, F., Labbe, O., Eggerickx, D., Vassart, G. and Parmentier, M. Molecular cloning. functional expression and pharmacologi- cal characterization of a mouse melanocortin receptor gene, Biochem. J. 299 (1994) 367-373.

[10] Edwards, P.M., Kuiters, R.R.F., Boer. G.J. and Gispen, W.H., Recovery from peripheral nerve transection is accelerated by local application of $\alpha$ MSH by means of microporous Accurel polypropylene tubes, J. Neurol. Sci., 74 (1986) 171-176.

[11] Frandsen, E.K. and Krishna, G.. A sensitive radioimmunoassay for the detection of cAMP, Life Sci., 18 (1977) 529.

[12] Gantz, I., Konda, T., Tashiro, T., Shimoto, Y.. Miwa, H., Munzert. G., Watson, S.J., DelValle, J. and Yamada. T., Molecular cloning of a novel melanocortin receptor. I. Biol. Chem. 268 (199.3) 82468250 .

[13] Gantz, I., Miwa, H., Konda, Y., Shimoto, Y., Tashiro, T., Watson. S.J., DelValle, J. and Yamada, T., Molecular cloning, expression, and gene localization of a fourth melanocortin receptor, J. Biol. Chem., 268 (1993) 15174-15179.

[14] Gantz, I., Shimoto, Y., Konda, Y., Miwa, H., Dickinson, C.J. and Yamada, T. Molecular cloning, expression, and characterization of a fifth melanocortin receptor. Biochem. Biophys. Re's. Commun., 2(K) (1994) 1214-1220.

[15] Griffon, N., Mignon, V., Facchinetti, P.. Diaz., J.. Schwartz, J-C. and Sokoloff. P., Molccular cloning and characterization of the rat fifth melanocortin receptor, Biochem. Biophys. Re's. Commun., 200)(1994) $1007-1014$.

[16] Haynes, L.W. and Semenenko, F.M., The trophic responses of avian scnsory ganglia in vitro to $N$-acetylated and des-acetyl forms of alpha-melanocytc stimulating hormone ( $\alpha$-MSH) are qualitatively distinct, Int. J. Dei. Neurosci., 7 (1989) 62.3-6.32.

[17] Hol, E.M., Van Essen, E.H.R., Gispen, W.H. and Bär, P.R., $\alpha$ MSH and $\mathrm{ACTH}_{4} \mathrm{q}_{4}$-analog Org2766 induce cAMP increase in primary cultures of rat spinal cord cells. Ann. NY Acad. Sci. 680 (199.3) 5.33-535. (Abstr.)

[18] Hol. E.M., Verhage. M.. Gispen. W.H. and Bar, P.R. The role of calcium and CAMP in the mechanism of action of two melanocortins: $\alpha \mathrm{MSH}$ and the ACTH 4-9 analogue Org 2766. Brain Res., 662 (1994) $109-116$.

[19] Hol, E.M.. Gispen, W.H. and Bar, P.R.. ACTH-related peptides: receptors and signal transduction systems involved in their neurotrophic and neuroprotective actions, Peptides. 16 (1995) $979-993$.

[20] Hughes, S. and Smith, M.E., Upregulation of the pro-opiomelanocortin gene in motoneurones after nerve section in mice. Mol. Brain Res., 25 (1994) 41-49.

[21] Jap Tjoen San, E.R.A., Schmidt-Michels, M., Spruyt, B.M., Schotman. P. and Gispen, W.H., Quantitation of the growth associated protein B50 (GAP-43) and neurite formation in P(12 cells. I. Neurosci. Res., 29 (1991) 149-154

[22] Katoh-Semba, R., Kitajima, S., Yamazaki, Y. and Sano. M., Neuritic outgrowth from a new subline of $\mathrm{PC} 12$ phenchromocytoma cells: cyclic AMP mimics the action of nerve growth factor, $J$ Neurosci. Res., 17 (1987) 36-44.

[23] Kumagai, C.. Tohda, M., Isobe. M. and Nomura, Y., Involvement of growht-associated protein-43 with irreversible neurite outgrowth by dibutyryl cyclic AMP and phorbol ester in NG 108-15 cells, $J$ Neurochem., 59 (1992) 41-47.

[24] Labbe, O., Desarnaud, F., Eggerickx, D.. Vassart. G. and Parmentier, M.. Molecular cloning of a mousc melanocortin 5 receptor gene widely expressed in peripheral lissues. Biochemistr? 33 (1994) $4543-4549$.

[25] Mountjoy, K.G., Robbins, L.S., Monrud, M.T. and Cone, R.D., The cloning of a family of genes that encode the melanocortin receptors, Science, 257 (1992) 1248-1251

[26] Mountjoy, K.G.. Mortrud, M.T.. Low. M.J., Simerley. R.B. and Cone, R.D., Cloning and functional characterization of a melanocortin receptor (MC4-R) localized in ncurocndocrinc and autonomic circuitry in the brain, Mol. Endocrinol. $8(1994) 1298-$ 1.308 .

[27] Nakagawa-Yagi, Y., Saito, Y., Takada, Y. and Nakamura, H. 
Suppresive effects of carbachol on forskolin-stimulated neurite outgrowth in human neuroblastoma NB-OK1 cells, Biochem. Biophys. Res. Commun., 182 (1992) 45-54.

[28] Pichichero, M., Effects of dibutyryl cyclic AMP on restoration of function of damaged sciatic nerve, Science, 182 (1973) 724-725.

[29] Plantinga, L.C., Verhaagen, J., Edwards, P.M., Schrama, L.H. Burbach, J.P.H. and Gispen, W.H., Expression of the pro-opiomelanocortin gene in dorsal root ganglia, spinal cord and sciatic nerve after sciatic nerve crush in the rat, Mol. Brain Res., 16 (1992) 135-142.

[30] Rehfuss-Roselli, L., Mountjoy, K.G., Robbins, L.S., Mortrud, M.T., Low, M.J., Tatro, J.B., Entwistle, M.L., Simerly, R.B. and Cone, R.D., Identification of a receptor for melanotropin and other proopiomelanocortin peptides in the hypothalamus and limbic system, Proc. Natl. Acad. Sci. USA, 90 (1993) 8856-8860.

[31] Rydel, R.E. and Greene, L.A., cAMP analogs promote survival and neurite outgrowth in vitro in cultures of rat sympathetic and sensory neurons independently of nerve growth factor, Proc. Natl. Acad. Sci. USA, 85 (1988) 1257-1261.

[32] Sambrook, J., Fritsch, E.F. and Maniatis, T. Molecular Cloning: A Laboratory Manual, Cold Spring Harbor Laboratory Press, Cold Spring Harbor, NY, 1989.

[33] Thomson, C.E., Griffiths, I.R., McCulloch, M.C., Kyriakides, E., Barrie, J.A. and Montague, P., In vitro studies of axonally-regulated
Schwann cell genes during Wallerian degeneration, J. Neurocytol., 22 (1993) 590-602.

[34] Van der Eb, A.J. and Graham, F.L., Assay for tranforming activity of tumor virus DNA, Methods Enzymol, 65 (1980) 826-839.

[35] Van der Neut, R., Bär, P.R., Sodaar, P. and Gispen, W.H., Trophic influences of $\alpha$ MSH and ACTH 4-10 on ncuronal outgrowth in vitro, Peptides, 9 (1988) 1015-1020.

[36] Van der Neut, R., Hol, E.M., Gispen, W.H. and Bär, P.R., Stimulation by melanocortins of neurite outgrowth from spinal and sensory ncurons in vitro, Peptides, 13 (1992) 1109-1115.

[37] Van Der Zee, C.E.E.M., Brakkec, J.H. and Gispen, W.H., $\alpha$ MSH and Org2766 in peripheral nerve regeneration: different routes of delivery, Eur. J. Pharmacol., 147 (1988) 351-357.

[38] Van Der Zec, C.E.E.M., Brakkee, J.H. and Gispen, W.H., Putative neurotrophic factors and functional recovery from peripheral nerve damage in the rat, Br. J. Pharmacol., 103 (1991) 1041-1046.

[39] Verhaagen, J.. Edwards, P.M., Jennekens, F.G.I., Schotman, P. and Gispen, W.H.. a-Melanocyte stimulating hormone stimulates the outgrowth of myelinated nerve fibers after peripheral nerve crush. Exp. Neurol., 92 (1986) 451-454.

[40] Wilkinson. M., A rapid and convenient method for isolation of nuclear, cytoplasmatic and total cellular RNA. Nucleic Acids Res., $16(1988) 109.34$. 